\title{
PENGARUH KOMPETENSI SUPERVISI DAN MANAJERIAL KEPALA MADRASAH TERHADAP MUTU PENDIDIKAN DI MADRASAH TSANAWIYAH SE-KECAMATAN GANTARANG KABUPATEN BULUKUMBA
}

\author{
NURHAYATI, ARIFUDDIN SIRA, MUHAMMAD YAUMI \\ Pascasarjana UIN Alauddin Makassar \\ JI. H. M. Yasin Limpo No. 36 Samata Gowa \\ Email: nurhayatispdi070@gmail.com, arifuddin.siraj@uin-alauddin.ac.id, \\ muhammad.yaumi@uin-alauddin.ac.id
}

\begin{abstract}
:
This study attempts to describe supervision competence and managerial competence of the heads schools, to describe educational quality of Islamic Junior High Schools (MTS), and then to analyze the influence of the supervision competence and managerial competence toward educational quality of MTS both partially and simultaneously in Gantarang District, Bulukumba Regency. This study is ex-post facto. The population is all the teachers of all private MTS with accredited A. It is analyzed all the teachers as the sample with 54 people of all. Method of data collection is through questionnaires about supervision competence, also using data analysis, and multiple regressions. The results of the study obtained that the supervision competence and the managerial competence of the head is in the medium category. The supervision competence of the head schools significantly influences the quality of education. The managerial competence of the head schools significantly influences the quality of education. Both supervision competence and managerial competence of the heads of schools have the significantly influencer toward educational quality of MTS, in Gantarang district, Bulukumba Regency.
\end{abstract}

Keywords: Supervision Competence, Managerial Competence, Education Quality

\section{PENDAHULUAN}

Dendidikan menjadi tumpuan harapan bagi peningkatan kualitas sumber daya manusia (SDM) bangsa Indonesia. Pendidikan menjadi sarana bagi pembentukan intelektualitas, bakat, budi pekerti/akhlak, dan kecakapan anak didik. Atas pertimbangan inilah selayaknya semua pihak perlu memberikan perhatian secara maksimal terhadap bidang pendidikan. Perhatian tersebut antara lain direalisasikan melalui kerja keras secara kontinu untuk memperbaharui dan meningkatkan kualitas pendidikan dari waktu ke waktu. Melalui cara demikian, pendidikan diharapkan mampu menjawab aneka macam kebutuhan, tuntutan dan permasalahan yang dihadapi masyarakat. Madrasah sebagai lembaga pendidikan harus meningkatkan kegiatan-kegiatan yang bukan saja untuk meningkatkan kompetensi lulusan melainkan juga kegiatan-kegiatan tersebut mampu mendisiplinkan peserta didik dan pegawai di madrasah khususnya guru sebagai aktor utama dalam proses pendidikan di madrasah.

Mutu pendidikan di madrasah menjadi sangat vital bagi peserta didik. Madrasah harus mampu mengatasi dan menjadi benteng bagi peserta didik dalam 
menghadapi kemajuan teknologi dan pergaulan bebas. Tentunya hal tersebut bisa tercapai jika ada kerja sama yang baik anatara pihak madrasah dan pihak orangtua peserta didik. Madrasah mempunyai peranan yang sangat besar dalam mencerdaskan kehidupan bangsa. Lembaga pendidikan (madrasah) dikatakan bermutu dan memiliki peran aktif dalam mencerdaskan kehidupan bangsa, salah satu indikasinya adalah jika terdapat pemimpin dan tenaga pendidik yang bertanggung jawab, profesional di bidangnya, dan memiliki nilai moral yang tinggi (Ruky, 2011). Berdasarkan pada Peraturan Menteri Agama RI Nomor 58 Tahun 2017 disebutkan bahwa madrasah adalah satuan pendidikan formal pada Kementerian Agama yang menyelenggarakan pendidikan umum dengan kekhasan agama Islam.

Madrasah dapat melahirkan manusia-manusia yang berilmu dan beriman jika manajemen madrasah dapat berjalan dengan baik dan benar. Peran madrasah sebagai wadah edukasi sangat vital demi melahirkan manusia-manusia berderajat tinggi yang oleh Allah sebut di dalam QS al-Mujāâliah/58:11:

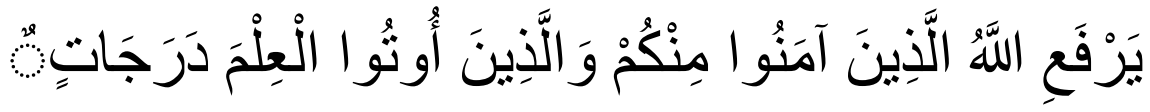

...Niscaya Allah akan meninggikan orang-orang yang beriman di antara kamu dan orang-orang yang berilmu pengetahuan beberapa derajat...

Kepala madrasah merupakan pemegang kebijakan di satuan pendidikan yang dituntut dapat memberikan sentuhan dan keterampilan yang dapat memberikan motivasi kepada para bawahannya yaitu tenaga pendidik dan tenaga kependidikan selaku pelaksana dalam mewujudkan visi misi madrasah. Keterampilan kepemimpinan bertujuan agar kepala madrasah dapat mengambil keputusan secara cepat, dan mampu mengendalikan, mempengaruhi, mengkoordinasikan serta mendorong bawahannya untuk melaksanakan tugas dengan jujur, bertanggung jawab, efektif dan efisien. Menurut Joenoes (1974), keberhasilan madrasah sangat ditentukan oleh kemampuan kepala madrasah mengelola tenaga pendidik, meningkatkan kinerja guru, bertanggung jawab atas penyelenggaraan kegiatan pendidikan, administrasi madrasah, pembinaan tenaga kependidikan lainnya, pendayagunaan, serta pemeliharaan sarana dan prasarana.

Di dalam Peraturan Menteri Agama Republik Indonesia Nomor 58 Tahun 2017 pasal 8 ayat 1 disebutkan bahwa kepala madrasah harus memiliki: 1) kompetensi kepribadian; 2) kompetensi manajerial; 3) kompetensi kewirausahaan; 4) kompetensi supervisi; dan kompetensi sosial. Lebih lanjut Masyhud mengatakan bahwa: Kompetensi yang harus dimiliki oleh seorang kepala madrasah sebagai pejabat profesional dalam bidang kependidikan (Masyhud, 2014, h. 24) adalah meliputi 4 kompetensi yang diwajibkan pada guru berdasarkan Undang-undang Nomor 14 Tahun 2005 tentang Guru dan Dosen, yaitu meliputi: 1) kompetensi pedagogik; 2) kompetensi kepribadian (personal); 3) kompetensi profesional; dan 4) kompetensi sosial. Di samping keempat kompetensi di atas, bagi guru yang mendapatkan tugas tambahan sebagai kepala madrasah masih diharuskan 
menguasai 3 macam kompetensi tambahan seperti yang diatur dalam Peraturan Menteri Pendidikan Nasional RI No. 13/2007. Ketiga kompetensi tersebut adalah meliputi: 1) kompetensi manajerial; 2) kompetensi kewirausahaan, dan 3) kompetensi supervisi.

Syafaruddin dalam Siraj (2014, h. 151) berpendapat bahwa keberhasilan suatu lembaga pendidikan dipengaruhi oleh kepala madrasah. Madrasah akan maju jika dipimpin oleh seorang kepala madrasah yang visioner, memiliki keterampilan manajerial, dan integrasi kepribadian dalam melakukan perbaikan di madrasah. Kepala madrasah memberi solusi untuk menjawab tantangan masa kini dan masa depan, karena kepala madrasah dapat membentuk pendidikan yang tanggap dan mampu merespon perubahan yang terjadi dalam bidang pendidikan. Kepala madrasah sebagai pejabat formal, karena pengangkatannya melalui proses yang berdasarkan peraturan yang berlaku di Indonesia. Sesuai dengan Peraturan Menteri Pendidikan Nasional Nomor 13 Tahun 2007 tentang Standar Kepala Madrasah (Wahyudi dalam Siraj, 2014: 151). Kepala madrasah menjadi faktor kunci dalam menciptakan madrasah yang unggul. Peranan sentral kepala madrasah dalam organisasi sangat dibutuhkan, dalam pengembangan kualitas pendidikan dan pembelajaran.

Kepala madrasah merupakan penentu arah kebijakan madrasah yang akan menentukan arah dan tujuan pendidikan dalam sebuah lembaga madrasah. Oleh karena itu, menurut E. Mulyasa dalam Siraj (2014, h. 151, kepala madrasah harus memenuhi kriteria sebagai berikut: 1) mampu memberdayakan guru-guru untuk melaksanakan proses pembelajaran dengan baik, lancar, dan produktif; 2) dapat menyelesaikan tugas dan pekerjaan sesuai dengan waktu yang telah ditetapkan; 3) mampu menjalin hubungan yang harmonis dengan masyarakat, sehingga dapat melibatkan mereka secara aktif dalam rangka mewujudkan tujuan madrasah dan pendidikan; 4) berhasil menerapkan prinsip kepemimpinan yang sesuai dengan tingkat kedewasaan guru dan pegawai lain di madrasah; 5) bekerja dengan tim manajemen; 6) berhasil mewujudkan tujuan madrasah secara produktif sesuai dengan ketentuan yang telah ditentukan. Berdasarkan uraian tersebut, maka penulis berpendapat bahwa peran kepala madrasah menempati posisi yang sangat strategis, karena maju tidaknya sebuah lembaga pendidikan/madrasah tergantung pada kualitas kepemimpinan kepala madrasah itu sendiri.

Supervisi adalah kegiatan mengamati, mengidentifikasi mana hal-hal yang sudah benar, mana yang belum benar, dan mana pula yang tidak benar dengan maksud agar tetap dengan tujuan memberikan bimbingan (Rikunto, 2004: 5). Dengan adanya pelaksanaan supervisi oleh kepala sekolah/madrasah diharapkan memberi dampak terhadap terbentuknya sikap profesionalisme guru (Ariana dkk, 2015: 1-5). Adams dan Dickey dalam Sahertian mendefinisikan supervisi adalah program yang berencana untuk memperbaiki pengajaran, program itu pada hakikatnya adalah perbaikan hal belajar dan mengajar (Sahertian, 2000: 17). 
Kompetensi supervisi kepala sekolah terkait dengan kemampuan kepala sekolah dalam menilai kinerja guru (Suhardiman, 2014: 48). Purwanto yang mengatakan bahwa tugas kepala sekolah sebagai supervisor berarti bahwa dia hendaknya pandai meneliti, menari dan menetukan syarat-syarat mana sajakah yang diperlukan bagi sekolahnya, sehingga tujuan-tujuan pendidikan di sekolah itu semaksimal mungkin dapat dicapai (Purwanto, 1998: 115).

Kepala sekolah sebagai supervisor dituntut memiliki dua kapabilitas sekaligus yaitu penguasaan model-model pembelajaran dan cara-cara memberikan bantuan kepada guru yang mengalami kesulitan dalam menerapkan model-model pembelajaran (Imron, 2012: 192). Penguasaan model-model pembelajaran yang dimaksud adalah cara guru dalam membantu, mengajar, membangun, melatih dan mengembangkan cara siswa dalam belajar. Ini dalam konteks saat siswa menerima, mengolah dan menerapkan pengetahuan yang diberikan oleh guru, ini bersifat substantif. Ini dikarenakan beberapa metode dan teknik pembelajaran yang dapat digunakan oleh guru, tetapi tidak semuanya sama efektifnya dapat mencapai tujuan pembelajaran (Uno, 2014: 7). Sedangkan cara-cara kepala sekolah memberikan bantuan kepada guru terkait dengan aspek psikologis guru. Kompetensi supervisi kepala sekolah yang tertuang dalam lampiran Peraturan Menteri Pendidikan Nasional Nomor 13 Tahun 2017 yaitu: 1) Merencanakan program supervisi akademik dalam rangka peningkatan profesional guru; 2) Melaksanakan supervisi akademik terhadap guru dengan menggunakan pendekatan dan teknik supervisi yang tepat; 3) Menindaklanjuti hasil supervisi akademik terhadap guru dalam rangka meningkatkan profesional guru.

Secara nasional, tujuan konkret dari supervisi pendidikan adalah: 1) membantu guru melihat dengan jelas tujuan pendidikan; 2) membantu guru membimbing pengalaman belajar murid; 3) membantu guru dalam menggunakan alat pelajaran modern, metode dan pengalaman belajar; 4) membantu dalam menilai kemajuan murid dan hasil pekerjaan guru itu sendiri (Soetopo dan Soemanto,1998: hal 41). Menurut Briggs bahwa fungsi utama supervisi bukan perbaikan pembelajaran saja, tetapi untuk mengkoordinasi, menstimulasi, dan mendorong ke arah pertumbuhan profesi guru. Ada analisis yang lebih luas seperti yang dikemukakan oleh Swearingen (1961) dalam Sahertian yang menjelaskan delapan fungsi supervisi: 1) mengkoordinasi semua usaha sekolah; 2) memperlengkapi kepemimpinan sekolah; 3) memperluas pengalaman guru-guru; 4) menstimulasi usaha-usaha yang kreatif; 5) memberi fasilitas dan penilaian yang terus menerus; 6) menganalisis situasi belajar-mengajar; 7) memberikan pengetahuan dan keterampilan kepada setiap anggota staf; dan (8) memberi wawasan yang lebih luas dan terintegrasi dalam merumuskan tujuan-tujuan pendidikan dan meningkatkan kemampuan mengajar guru-guru. Prinsip-prinsip supervisi adalah: prinsip ilmiah, prinsip demokratis, prinsip koperatif, prinsip konstruktif dan kreatif. Menurut Pangaribuan yang dikemukakan oleh Sagala (2013, h. 199) bahwa prinsip-prinsip 
yang harus dijadikan pedoman dan diterapkan dalam mengembangkan supervisi adalah: ilmiah, kooperatif, realistik, progresif, dan inovatif. Kompetensi supervisi kepala madrasah $\left(X_{1}\right)$ yang dimaksud dalam penelitian ini adalah kemampuan kepala madrasah dalam merencanakan program supervisi akademik dalam rangka peningkatan profesional guru, kemampuan melaksanakan supervisi akademik terhadap guru dengan menggunakan pendekatan dan teknik supervisi yang tepat, kemampuan menindak lanjuti hasil supervisi akademik terhadap guru dalam rangka meningkatkan profesional guru.

Secara etimologi, manajemen berasal dari bahasa Inggris to manage sinonim to hand berarti mengurus, to control berarti memeriksa, to guide berarti memimpin. Sedangkan secara terminologi manajemen sering diartikan sebagai ilmu, kiat dan profesi. Dikatakan sebagai ilmu oleh Gulick karena manajemen dipandang sebagai suatu bidang pengetahuan yang secara sistematis berusaha memahami mengapa dan bagaimana orang bekerja sama (Fattah, 2013: 1). Rifai (2004) mengutip pendapat Fayol bahwa semua manajer menjalankan fungsi manajemen, yaitu merencanakan, mengorganisasi, mengkoordinasi, dan mengendalikan, yang dewasa ini disebut juga perencanaan, pengorganisasian, kepemimpinan, dan pengendalian.

Kompetensi manajerial kepala sekolah yang tertuang dalam lampiran Peraturan Menteri Pendidikan Nasional Nomor 13 Tahun 2017 yaitu: 1) menyusun perencanaan sekolah/madrasah untuk berbagai tingkatan perencanaan; 2) mengembangkan organisasi sekolah/madrasah sesuai dengan kebutuhan; 3) memimpin sekolah/madrasah dalam rangka pendayagunaan sumber daya sekolah/madrasah secara optimal; 4) mengelola perubahan dan pengembangan sekolah/madrasah menuju organisasi pembelajar yang efektif; 5) menciptakan budaya dan iklim sekolah/madrasah yang kondusif dan inovatif bagi pembelajar peserta didik; 6) mengelola guru dan staf dalam rangka pendayagunaan sumber daya manusia secara optimal; 7) mengelola sarana dan prasarana sekolah/madrasah dalam rangka pendayagunaan secara optimal; 8) mengelola hubungan sekolah/madrasah dan masyarakat dalam ranngka pencarian dukungan ide, sumber belajar dan pembiayaan sekolah/madrasah; 9) mengelola peserta didik dalam rangka penerimaan peserta didik baru, dan penempatan dan pengembangan kapasitas peserta didik; 10) mengelola pengembangan kurikulum dan kegiatan pembelajaran sesuai dengan arah dan tujuan pendidikan nasional; 11) mengelola keuangan sekolah/madrasah sesuai dengan prinsip pengelolaan yang akuntabel, transparan dan efisien; 12) mengelola ketatausahaan sekolah/madrasah dalam mendukung pencapaian tujuan sekolah/madrasah; 13) mengelola unit layanan khusus sekolah/madrasah dalam mendukung kegiatan pembelajaran dan kegiatan peserta didik di sekolah/madrasah; 14) mengelola sistem informasi sekolah/madrasah dalam mendukung penyusunan program dan pengambilan keputusan; 15) memanfaatkan kemajuan teknologi informasi bagi peningkatan pembelajaran dan manajemen sekolah/madrasah; dan 16) melakukan monitoring, 
evaluasi, dan pelaporan pelaksanaan program kegiatan sekolah/madrasah dengan prosedur yang tepat serta merencanakan tindak lanjutnya.

Menurut Mulyasa (2013) dalam rangka melakukan peran dan fungsinya sebagai manajer, kepala madrasah harus memiliki strategi yang tepat untuk memberdayakan tenaga kependidikan melalui kerja sama atau kooperatif, memberikan kesempatan kepada para tenaga kependidikan untuk meningkatkan profesinya, dan mendorong keterlibatan seluruh tenaga kependidikan dalam berbagai kegiatan yng menunjang program madrasah. Penjelasan dari Mulyasa tersebut dapat dipahami bahwa memberdayakan tenaga kependidikan melalui kerja sama atau kooperatif dimaksudkan untuk peningkatan profesionaliame tenaga kependidikan di madrasah. Kepala madrasah harus mementingkan kerjasama dengan tenaga kependidikan dan pihak lain yang terkait dalam melaksanakan setiap kegiatan. Sebagai manajer kepala madrasah harus mau dan mampu mendayagunakan seluruh sumber daya madrasah dalam rangka mewujudkan visi dan misi dalam rangka mencapai tujuan.

Kepala sekolah harus mampu bekerja melalui orang lain (wakil-wakilnya) dan berusaha untuk senantiasa mempertanggungjawabkan setiap tindakan. Kepala madrasah sebagai manajer memiliki ketangkasan dan keterampilan khusus dalam rangka mengusahakan berbagai kegiatan yang saling berkaitan dan didayagunakan untuk mencapai tujuan yang telah direncanakan.

Dalam mengusahakan berbagai kegiatan, biasanya melalui proses manajemen kepala madrasah yang dapat diuraikan sebagai berikut: 1) perencanaan, merupakan proses berkesinambungan berupa kegiatan-kegiatan diagnosa, pengumpulan data, perumusan masalah, perumusan kebutuhan, peninjauan dan pemilihan sumber, penentuan faktor penunjang dan faktor penghambat, alternatif pemecahan masalah, pengambilan keputusan, pembuatan jadwal kegiatan monitoring, dan evaluasi (Moh. Holili,2006). Proses perencanaan di madrasah harus dilakukan secara kolaboratif, maksudnya dengan mengikutsertakan personal madrasah dalam semua tahap perencanaan. Pengikutsertaan ini akan menimbulkan perasaan ikut memiliki (sense of belanging) yang dapat memberikan dorongan kepada guru dan personal madrasah yang lain untuk berusaha agar rencana tersebut berhasil. Pada proses ini kepala madrasah harus benar-benar memikirkan dan merumuskan dalam suatu program tujuan dan tindakan-tindakan yang harus dilakukan. 2) pengorganisasian, di madrasah dapat didefinisikan sebagai keseluruhan proses untuk memilih dan memilah orang-orang (guru dan personal madrasah serta mengalokasikan prasarana dan sarana untuk menunjang tugas orang-orang itu dalam rangka mencapai tujuan madrasah. Termasuk di dalam kegiatan pengorganisasian, adalah penetapan tugas, tanggung jawab, dan wewenang orang-orang tersebut serta mekanisme kerjanya, sehingga dapat menjamin tercapainya tujuan madrasah itu; 3) penggerakan, kegiatan pengarahan dapat dilakukan dengan berbagai cara, antara lain dengan melaksanakan orientasi tentang pekerjaan yang akan dilakukan oleh individu atau 
kelompok, dan memberikan petunjuk umum dan petunjuk khusus baik secara lisan maupun tertulis, secara langsung maupun tidak langsung; 4) pengawasan, secara nasional tujuan konkrit supervisi pendidikan adalah membantu guru melihat dengan jelas tujuan-tujuan pendidikan, membantu guru dalam membimbing pengalaman belajar peserta didik, membantu guru dalam menggunakan alat pelajaran modern, metode-metode dan sumber-sumber pengalaman belajar, membantu guru dalam menilai kemajuan peserta didik dan hasil pekerjaan guru itu sendiri, membantu guruguru baru di madrasah, sehingga mereka merasa gembira dengan tugas yang diperolehnya, membantu guru-guru agar waktu dan tenaganya tercurahkan sepenuhnya dalam pembinaan madrasah.

Kompetensi manajerial kepala madrasah $\left(\mathrm{X}_{2}\right)$ yang dimaksud dalam penelitian ini adalah kemampuan kepala madrasah dalam: 1) menyusun perencanaan madrasah; 2) mengembangkan organisasi madrasah; 3) pendayagunaan sumber daya madrasah; 4) mengelola perubahan dan pengembangan madrasah; 5) menciptakan budaya dan iklim madrasah; 6) mengelola guru dan staf; 7) mengelola sarana dan prasarana madrasah; 8) mengelola hubungan madrasah dan masyarakat; 9) mengelola peserta didik; 10) mengelola pengembangan kurikulum; 11) mengelola keuangan sekolah; 12) mengelola ketatausahaan madrasah; 13) mengelola unit layanan khusus madrasah; 14) mengelola sistem informasi madrasah; 15) memanfaatkan kemajuan teknologi; 16) melakukan monitoring, evaluasi, dan pelaporan pelaksanaan program kegiatan madrasah.

Mutu mengandung dua hal, yaitu sifat (keadaan) dan (taraf) kedudukan. Akan tetapi setiap orang memiliki pandangan yang berbeda mengenai sifat dan taraf tersebut. Menurut Tony Bush dan Mariannecoleman (2006), mutu adalah pemenuhan terhadap kebutuhan stakeholder, bersistem pencegahan, mempunyai standar tanpa cacat dan mempunyai ukuran harga ketidakpuasan. Bila dikaitkan dengan madrasah mutu akan berkenaan dengan segala aspek yang berhubungan dengan segala kegiatan yang dilaksanakan dalam rangka mendidik di dalam suatu madrasah. Mutu dalam bidang pendidikan meliputi mutu input, output dan outcomes. Input pendidikan dinyatakan bermutu jika siap berproses, proses pendidikan bermutu apabila mampu menciptakan suasana yang PAIKEM (Pembelajaran Aktif, Inovatif, Kreatif, Efektif dan Menyenangkan). Output pendidikan dikatakan bermutu jika hasil belajar akademiki maupun non akademik peserta didik tinggi. Outcome dinyatakan bermutu apabila lulusan terserap di dunia kerja, gaji wajar, semua pihak mengakui kehebatan Iulusan dan merasa puas (Usman, 2004).

Adapun yang dapat memberikan pengaruh terhadap mutu pendidikan, diantaranya adalah guru, peserta didik, kepala sekolah, partisipasi masyarakat, sarana dan prasarana (Zuhairini dan Ghofir, 2014). Mutu di bidang pendidikan meliputi mutu input, proses, output, dan outcome. Input pendidikan dinyatakan bermutu jika siap berproses. Proses pendidikan bermutu apabila mampu menciptakan suasana yang PAKEM (Pembelajaran yang Aktif, Kreatif, dan 
Menyenangkan). Output dinyatakan bermutu apabila hasil belajar akademik dan non akademik siswa tinggi. Outcome dinyatakan bermutu apabila lulusan cepat terserap di dunia kerja, gaji wajar, semua pihak mengakui kehebatan lulusannya dan merasa puas (Husaini, 2006). Mutu pendidikan (Y) yang dimaksud dalam penelitian ini adalah hasil atau prestasi madrasah dalam kurun waktu 3 tahun terakhir. Mutu pendidikan yang dimaksud dalam penelitian ini meliputi mutu input, proses, dan output yang tercermin melalui sertifikat hasil akreditasi madrasah.

Berdasarkan hasil observasi di Madrasah Tsanawiyah Bontosungguh Kecamatan Gantarang Kabupaten Bulukumba ditemukan beberapa fakta bahwa masih terdapat siswa yang meninggalkan kelas di saat jam sekolah. Demikian pula beberapa guru masih belum mahir menggunakan laptop atau komputer dan beberapa tindakan kurang disiplin guru dalam menjalankan tugas dan fungsinya, maka peneliti berinisiatif melakukan penelitian. Tujuan penelitian adalah untuk mengetahui kompetensi supervisi kepala madrasah, kompetensi manajerial kepala madrasah, dan mutu pendidikan di Madrasah Tsanawiyah se-Kecamatan Gantarang Kabupaten Bulukumba dan untuk menganalisis pengaruh kompetensi supervisi dan kompetensi manajerial kepala madrasah terhadap mutu pendidikan di Madrasah Tsanawiyah se-Kecamatan Gantarang Kabupaten Bulukumba.

\section{METODE PENELITIAN}

Penelitian ini merupakan jenis penelitian ex post facto. Paradigma penelitian ini terdiri atas dua variabel independen yaitu kompetensi supervisi kepala madrasah (X1) dan kompetensi manajerial kepala madrasah (X2) dan satu variabel dependen (terikat) yaitu mutu pendidikan. Lokasi penelitian yaitu di Madrasah Tsanawiyah seKecamatan Gantarang Kabupaten Bulukumba. Populasi yang menjadi objek penelitian dalam penelitian ini adalah seluruh guru di Madrasah Tsanawiyah seKecamatan Gantarang Kabupaten Bulukumba yang berstatus madrasah swasta terakreditasi A yang berjumlah 54 orang. Teknik pengambilan sampel yang digunakan dalam penelitian ini adalah teknik sampel jenuh. Metode pengumpulan data menggunakan angket dan dokumentasi. Instrumen yang digunakan dalam penelitian ini adalah angket kompetensi supervisi kepala madrasah, angket kompetensi manajerial kepala madrasah, dan dokumentasi sertifikat hasil akreditasi untuk pemerolehan data mutu pendidikan. Teknik analisis data yang digunakan dalam penelitian ini adalah analisis statistik deskriptif dan analisis statistik inferensial.

Analisis deskriptif digunakan terutama untuk mendeskripsikan data penelitian secara umum. Statistik yang digunakan meliputi skor tertinggi, skor terendah, mean (rata-rata), dan standar deviasi. Menurut Saifuddin Azwar (2013), analisis deskriptif menggunakan kategorisasi dengan rumus sebagai berikut:

$$
\begin{gathered}
\text { Rendah : } \bar{x}<(\mu-1,0(\sigma)) \\
\text { Sedang: }(\mu-1,0(\sigma)) \leq \bar{x}<(\mu+1,0(\sigma))
\end{gathered}
$$




$$
\text { Tinggi : } \bar{x} \geq(\mu-1,0(\sigma))
$$

Keterangan $\mu:$ Mean

$\sigma:$ Standar deviasi

Analisis inferensial digunakan untuk menguji hipotesis penelitian. Pengujian hipotesis dalam penelitian ini menggunakan uji regresi pada aplikasi SPSS for Windows. Kriteria pengujiannya dengan memperhatikan output olahan data. Namun, sebelum dilakukan pengujian hipotesis terlebih dahulu dilakukan uji prasyarat yaitu uji normalitas, uji linear, dan uji korelasi. Uji normalitas data dimaksudkan untuk mengetahui apakah data sampel berasal dari populasi berdistribusi normal atau tidak. Uji linearitas digunakan untuk memastikan apakah data yang kita miliki sesuai dengan garis linear atau tidak. Data dikatakan linear apabila memenuhi kriteria yang digunakan yakni $p$-value (sign) $\geq \alpha=0,05$. Uji korelasi dimaksudkan untuk mengetahui keeratan hubungan/korelasi antar variabel $\mathrm{X}$ dan variabel $\mathrm{Y}$.

\section{HASIL PENELITIAN DAN PEMBAHASAN}

Hasil analisis statistik deskriptif dan kategorisasi kompetensi supervisi dan manajerial kepala madrasah, serta mutu pendidikan di Madrasah Tsanawiyah SeKecamatan Gantarang Kabupaten Bulukumba disajikan pada Tabel 1 berikut:

Tabel 1. Statistik Deskriptif Kompetensi Supervisi dan Manajerial Kepala Madrasah, serta Mutu Pendidikan di Madrasah Tsanawiyah se-Kecamatan Gantarang Kabupaten Bulukumba

\begin{tabular}{lccc}
\hline \multicolumn{1}{c}{ Statistik } & Kompetensi Supervisi & $\begin{array}{c}\text { Nilai Statistik } \\
\text { Kompetensi } \\
\text { Manajerial }\end{array}$ & $\begin{array}{c}\text { Mutu } \\
\text { Pendidikan }\end{array}$ \\
\hline Skor terendah & & 197 & 76 \\
Skor tertinggi & 108 & 228 & 98 \\
Rata-rata & 101,43 & 216,4 & 87,28 \\
Standar deviasi & 3,27 & 6,92 & 4,85 \\
\hline
\end{tabular}

Sumber: Data diolah, 2019

Tabel 2. Kategorisasi Kompetensi Supervisi dan Manajerial Kepala Madrasah, serta Mutu Pendidikan di Madrasah Tsanawiyah Se-Kecamatan Gantarang Kabupaten Bulukumba

\begin{tabular}{|c|c|c|c|}
\hline \multicolumn{4}{|c|}{ Kategorisasi Skor Kompetensi Supervisi Kepala Madrasah } \\
\hline Batas Kategori & Frekuensi & Persentase (\%) & Kategor \\
\hline$x \geq 104,70$ & 9 & 16,67 & Tinggi \\
\hline $98,16 \leq x<104,70$ & 33 & 61,11 & Sedang \\
\hline$x<98,16$ & 12 & 22,22 & Rendah \\
\hline Jumlah & 54 & 100 & \\
\hline \multicolumn{4}{|c|}{ II. Kategorisasi Skor Kompetensi Manajerial Kepala Madrasah } \\
\hline Batas Kategori & Frekuensi & Persentase (\%) & Kategor \\
\hline$x \geq 223,33$ & 10 & 18,52 & Tinggi \\
\hline $209,49 \leq x<223,33$ & 33 & 61,11 & Sedang \\
\hline$x<209,49$ & 11 & 20,37 & Rendah \\
\hline Jumlah & 54 & 100 & \\
\hline \multicolumn{4}{|c|}{ III. $\quad$ Kategorisasi Skor Mutu Pendidikan di Madrasah Tsanawiyah } \\
\hline Batas Kategori & Frekuensi & Persentase (\%) & Kategor \\
\hline$x \geq 92,13$ & 9 & 16,67 & Tinggi \\
\hline $82,43 \leq x<92,13$ & 37 & 68,52 & Sedang \\
\hline$x<82,43$ & 8 & 14,81 & Rendah \\
\hline Jumlah & 54 & 100 & \\
\hline
\end{tabular}

sumber Data diolah, 2019 
Berdasarkan Tabel 1 dan 2 diperoleh informasi bahwa skor rata-rata kompetensi supervisi kepala madrasah di Madrasah Tsanawiyah di Kecamatan Gantarang Kabupaten Bulukumba adalah 101,43 dan termasuk kategori sedang. Aseltine mengemukakan "supervision offers a refreshing alternative to the ritualistic and marginally effective evaluation practices that teachers and administrators have endured". Menurut Imam Gunawan (2014), supervisi merupakan alternatif kegiatan pemberian bantuan berupa penyegaran yang berkelanjutan dan keefektifan kegiatan pembelajaran guru dievaluasi dan administrator sebagai penanggung jawab kegiatan terebut.

Supervisor melakukan kegiatan supervisi kepada guru secara berkelanjutan, sistematis, dan komprehensif. Hasil dari kegiatan supervisi dianalisis dan disimpulkan bersama oleh supervisor dan guru, sebagai dasar dalam kegiatan pembelajaran berikutnya. Peran kepala sekolah/madrasah adalah sebagai pendidik (educator), supervisor, pemimpin (leader), manajer, administrator, inovator, dan motivator. Kepala madrasah sebagai supervisor diharapkan dapat melaksanakan tugasnya dengan melakukan supervisi terhadap proses pembelajaran guru di kelas. Kepala madrasah dalam melakukan supervisi pengajaran bisa mendorong guru menerapkan kemampuannya dalam melaksanakan tugas-tugas mengajarnya, mendorong guru mengembangkan kemampuan sendiri, serta mendorong guru agar memiliki perhatian yang sungguh-sungguh (commitment) terhadap tugas dan tanggung jawabnya, sehingga melalui supervisi pengajaran, kepala madrasah sebagai supervisor bisa menumbuhkan motivasi kerja guru sekaligus meningkatkan kualitas pembelajaran di kelas (Henny, 2012).

Berdasarkan Tabel 1 dan 2 diperoleh informasi bahwa skor rata-rata kompetensi manajerial kepala madrasah di Madrasah Tsanawiyah Kecamatan Gantarang Kabupaten Bulukumba adalah 216,4 dan termasuk kategori sedang. Kepala madrasah sebagai manager harus mampu memaksimalkan kemampuan manajerialnya dalam melaksanakan fungsi manajemen yang mencakup kegiatan perencanaan, pengorganisasian, penggerakan, dan pengawasan untuk mencapai sasaran yang telah ditetapkan melalui pemanfaatan sumber daya manusia dan sumber daya lainnya. Tugas dan tanggung jawab kepala madrasah adalah merencanakan, mengorganisasikan, mengarahkan, mengkoordinasikan, mengawasi dan mengevaluasi seluruh kegiatan madrasah dengan menggunakan sumber daya yang ada (Kusnan, 2017).

Berdasarkan Tabel 1 dan 2 diperoleh informasi bahwa skor rata-rata mutu pendidikan di Madrasah Tsanawiyah di Kecamatan Gantarang Kabupaten Bulukumba adalah 87,28 dan termasuk kategori sedang. Mutu pendidikan tidak bisa berdiri sendiri namun memerlukan kerja sama yang sinergi dari beberapa komponen yang terlibat langsung maupun tidak langsung. Standar nasional pendidikan dalam Peraturan Pemerintah Nomor 19 Tahun 2005 merupakan kriteria minimal tentang sistem pendidikan di seluruh wilayah hukum Negara Kesatuan Republik Indonesia 
dalam Bab II pasal 2 dinyatakan bahwa lingkup Standar Nasional Pendidikan menguraikan bahwa standar isi, standar proses, standar kompetensi lulusan, standar pendidik dan tenaga kependidikan, standar sarana prasarana, standar pengelolaan, standar pembiayaan, dan standar penilaian pendidikan. Mulyasana (2016) menyebutkan bahwa terdapat beberapa faktor dalam upaya menciptakan pendidikan yang bermutu, antara lain materi yang baik, perencanaan pendidikan yang baik, tata kelola pendidikan yang baik, dan pendidikan yang bermutu lahir dari guru yang bermutu.

Hasil uji normalitas data kompetensi supervisi kepala madrasah, kompetensi manajerial kepala madrasah, dan mutu pendidikan diperoleh nilai $p$ berturut-turut 0,$083 ; 0,200 ; 0,057$. Berdasarkan kriteria pengujian $p$-value $\geq \alpha(\alpha=0,05)$, dengan demikian dapat dikatakan bahwa data kompetensi supervisi kepala madrasah, data kompetensi manajerial kepala madrasah, dan data mutu pendidikan berasal dari populasi berdistribusi normal. Hasil uji linearitas linearitas antara mutu pendidikan $(\mathrm{Y})$ atas kompetensi supervisi kepala madrasah $\left(\mathrm{X}_{1}\right)$ adalah 0,717 . Berdasarkan kriteria pengujian, $p$-value $\geq \alpha(0,717 \geq 0,05)$, sehingga dapat dikatakan bahwa data mutu pendidikan $(\mathrm{Y})$ atas kompetensi supervisi kepala madrasah $\left(\mathrm{X}_{1}\right)$ adalah linear atau berupa garis linear/lurus. Sedangkan nilai $p$ pengujian linearitas antara mutu pendidikan $(\mathrm{Y})$ atas kompetensi manajerial kepala madrasah $\left(\mathrm{X}_{2}\right)$ adalah 0,670. Berdasarkan kriteria pengujian, $p$-value $\geq \alpha(0,670 \geq 0,05)$, sehingga dapat dikatakan bahwa data mutu pendidikan $(\mathrm{Y})$ atas kompetensi manajerial kepala madrasah $\left(\mathrm{X}_{2}\right)$ adalah linear atau berupa garis linear/lurus. Nilai r pengujian korelasi antara variabel kompetensi supervisi kepala madrasah $\left(X_{1}\right)$ dan variabel mutu pendidikan $(Y)$ adalah $r_{x 1 y}=0,346$. Berdasarkan pedoman yang diuraikan, nilai $\boldsymbol{r}_{\boldsymbol{x} \mathbf{y}}>0$, sehingga dapat dikatakan bahwa telah terjadi hubungan yang linear positif antara variabel kompetensi supervisi kepala madrasah $\left(X_{1}\right)$ dan variabel mutu pendidikan (Y). Sedangkan keeratan hubungan/korelasi antara variabel kompetensi supervisi kepala madrasah $\left(\mathrm{X}_{1}\right)$ dan variabel mutu pendidikan $(\mathrm{Y})$ yakni memiliki korelasi yang lemah tapi pasti karena berdasarkan pedoman yang diuraikan, nilai $r_{x 1 y}$ $=0,346$ berada pada interval $\mathbf{0 , 2 0}<\boldsymbol{r} \leq \mathbf{0 , 4 0}$ yang bermakna korelasi yang lemah tetapi pasti. Sedangkan, nilai $r$ pengujian korelasi antara variabel kompetensi manajerial kepala madrasah $\left(\mathrm{X}_{2}\right)$ dan variabel mutu pendidikan $(\mathrm{Y})$ adalah $r_{x 2 y}=$ 0,331 . Berdasarkan pedoman yang diuraikan, nilai $\boldsymbol{r}_{x \mathbf{y} y}>0$, sehingga dapat dikatakan bahwa telah terjadi hubungan yang linear positif antara variabel kompetensi manajerial kepala madrasah $\left(\mathrm{X}_{2}\right)$ dan variabel mutu pendidikan $(\mathrm{Y})$. Sedangkan keeratan hubungan/korelasi antara variabel kompetensi manajerial kepala madrasah $\left(\mathrm{X}_{2}\right)$ dan variabel mutu pendidikan $(\mathrm{Y})$ yakni memiliki korelasi yang lemah tapi pasti karena berdasarkan pedoman yang diuraikan, nilai $r_{x 2 y}=0,331$ berada pada interval $\mathbf{0 , 2 0}<\boldsymbol{r} \leq \mathbf{0 , 4 0}$ yang bermakna korelasi yang lemah tapi pasti. Nilai $r$ pengujian korelasi antara variabel kompetensi supervisi kepala 
madrasah $\left(\mathrm{X}_{1}\right)$ dan variabel kompetensi manajerial kepala madrasah $\left(\mathrm{X}_{2}\right)$ dengan variabel mutu pendidikan $(\mathrm{Y})$ adalah $r_{x 1 x 2 y}=0,432$. Berdasarkan pedoman yang diuraikan, nilai $\boldsymbol{r}_{\boldsymbol{x} \mathbf{1} x \mathbf{y} y}>0$, sehingga dapat dikatakan bahwa telah terjadi hubungan yang linear positif antara variabel kompetensi supervisi kepala madrasah $\left(X_{1}\right)$ dan variabel kompetensi manajerial kepala madrasah $\left(\mathrm{X}_{2}\right)$ dengan variabel mutu pendidikan $(Y)$. Sedangkan keeratan hubungan/korelasi antara variabel kompetensi supervisi kepala madrasah $\left(X_{1}\right)$ dan variabel kompetensi manajerial kepala madrasah $\left(\mathrm{X}_{2}\right)$ dengan variabel mutu pendidikan $(\mathrm{Y})$ yakni memiliki korelasi yang cukup berarti karena berdasarkan pedoman yang diuraikan, nilai $r_{x 1 \times 2 y}=0,432$ berada pada interval $\mathbf{0 , 4 0}<\boldsymbol{r} \leq \mathbf{0 , 7 0}$ yang bermakna korelasi yang cukup berarti.

Bentuk persamaan regresi variabel mutu pendidikan $(Y)$ atas kompetensi supervisi kepala madrasah $\left(X_{1}\right)$ yaitu $\widehat{Y}_{1}=32,864+0,534 X_{1}$. bentuk persamaan regresi variabel mutu pendidikan $(Y)$ atas kompetensi manajerial kepala madrasah $\left(X_{2}\right)$ yaitu $\widehat{Y}_{2}=36,740+0,232 X_{2}$. bentuk persamaan regresi variabel mutu pendidikan $(Y)$ atas variabel kompetensi supervisi kepala madrasah $\left(X_{1}\right)$ dan kompetensi manajerial kepala madrasah $\left(\mathrm{X}_{2}\right)$ yaitu $\hat{Y}=1,756+0,441 \mathrm{X} 1+$ $0,187 \mathrm{X} 2$.

Hasil uji hipotesis pengaruh kompetensi supervisi kepala madrasah $\left(\mathrm{X}_{1}\right)$ terhadap variabel mutu pendidikan $(Y)$, diperoleh nilai $p=\mathbf{0 , 0 1 0}$. Berdasarkan kriteria pengujian hipotesis, $p$-value $<\alpha(0,010<0,05)$ sehingga $\mathrm{H}_{0}$ ditolak. Dengan demikian, dapat dikatakan bahwa kompetensi supervisi kepala madrasah berpengaruh terhadap mutu pendidikan di Madrasah Tsanawiyah se-Kecamatan Gantarang Kabupaten Bulukumba. Supervisi pendidikan Islam dibutuhkan dalam rangka memberikan panduan dan arahan guna mengembangkan kemampuan individu sekaligus dalam upaya meningkatkan kualitas pendidikan. Bentuk atau pola supervisi yang tepat akan mempengaruhi tingkat kesuksesan dalam berbagai tingkat kinerja pendidikan yang relevan dan efektif (Fauzah, 2017). Supervisi sangat berpengaruh terhadap kemampuan profesional guru. Dengan adanya pelaksanaan supervisi yang teratur guru akan selalu berusaha memperbaiki kompetensi yang dimilikinya ke arah yang lebih baik, dengan adanya perbaikan kompetensi akan berpengaruh pula terhadap kegiatan pembelajaran yang semakin baik sehingga menghasilkan peserta didik berkualitas sesuai dengan tujuan pendidikan nasional (Bermawi \& Fauziah, 2015).

Hasil uji hipotesis pengaruh kompetensi manajerial kepala madrasah $\left(\mathrm{X}_{2}\right)$ terhadap variabel mutu pendidikan $(Y)$, diperoleh nilai $\boldsymbol{p}=\mathbf{0 , 0 1 5}$. Berdasarkan kriteria pengujian hipotesis $p$-value $<\alpha(0,015<0,05)$ sehingga $\mathrm{H}_{0}$ ditolak. Dengan demikian, dapat dikatakan bahwa kompetensi manajerial kepala madrasah berpengaruh terhadap mutu pendidikan di Madrasah Tsanawiyah se-Kecamatan Gantarang Kabupaten Bulukumba. Upaya meningkatkan mutu pendidikan terletak pada kemampuan suatu lembaga dalam merumuskan visinya. Terkait dengan 
lembaga madrasah tsanawiyah, kepala madrasah dengan kompetensi manajerial yang dimilikinya memegang peranan strategis dalam merumuskan/merencanakan dan merealisasikan visi madrasah. Nata menjelaskan bahwa strategi peningkatan kualitas pendidikan Islam bertumpu pada kemampuan memperbaiki dan merumuskan visi setiap zaman yang dituangkan dalam rumusan tujuan pendidikan yang jelas. Tujuan tersebut selanjutnya dituangkan dalam program pendidikan yang aplikable, metode dan pendekatan yang partisipatif, guru yang berkualitas, lingkungan pendidikan yang kondusif serta sarana dan prasarana yang menunjang (Abdullah Nata, 2013).

Hasil uji hipotesis pengaruh kompetensi supervisi kepala madrasah $\left(X_{1}\right)$ dan kompetensi manajerial kepala madrasah $\left(\mathrm{X}_{2}\right)$ secara bersama terhadap variabel mutu pendidikan $(\mathrm{Y})$, diperoleh nilai $p=\mathbf{0 , 0 0 5}$. Berdasarkan kriteria pengujian hipotesis, $p$-value $<\alpha(0,005<0,05)$ sehingga $\mathrm{H}_{0}$ ditolak. Dengan demikian, dapat dikatakan bahwa kompetensi supervisi kepala madrasah dan kompetensi manajerial kepala madrasah berpengaruh secara bersama terhadap mutu pendidikan di Madrasah Tsanawiyah se-Kecamatan Gantarang Kabupaten Bulukumba. Pendidikan bermutu lahir dari sistem perencanaan yang baik (good planning system) dengan materi dan sistem tata kelola yang baik (good governance system) dan disampaikan oleh guru yang baik/cerdas (good teacher) dengan komponen pendidikan yang bermutu pula (Iskandar dan Wibowo, 2016).

Selain itu, mutu pendidikan tidak terlepas dari peran supervisi pendidikan. Supervisi pendidikan di lingkup internal madrasah dilaksanakan oleh kepala madrasah. Supervisi pendidikan berperan untuk mengawasi kegiatan jalannya pendidikan, dan memperbaiki kekurangan atau kesalahan dalam proses pendidikan untuk meningkatkan mutu pendidikan. Mutu pendidikan dapat dilihat dari prestasi akademik dan non akademik peserta didik dalam kancah nasional dan internasional, sehingga keberhasilan pelaksanaan supervisi pendidikan dapat diukur dari peningkatan prestasi belajar peserta didik. Supervisi adalah ilmu tentang cara membina sumber daya manusia yang berperan pada pelaksanaan pendidikan yaitu pendidik untuk mencapai tujuan yang telah disepakati dan dijalankan oleh supervisor yaitu pengawas dan kepala sekolah. Supervisor berperan mengawasi, memimpin, membina, mengontrol sumber daya yang meliputi perencanaan, pengamatan, pembinaan, dan pengawasan (Nasution, 2015).

Berdasarkan teori dan temuan dalam penelitian ini menegaskan bahwa pentingnya kompetensi supervisi dan kompetensi manajerial kepala madrasah dalam meningkatkan mutu pendidikan.

\section{PENUTUP/SIMPULAN}

\section{Simpulan}

1. Hasil perhitungan statistik deskriptif kompetensi supervisi kepala madrasah di Madrasah Tsanawiyah se-Kecamatan Gantarang Kabupaten Bulukumba diperoleh rata-rata yaitu 101,43 berada pada kategori sedang. 
2. Hasil perhitungan statistik deskriptif kompetensi manajerial kepala madrasah di Madrasah Tsanawiyah se-Kecamatan Gantarang Kabupaten Bulukumba diperoleh rata-rata yaitu 216,4 berada pada kategori sedang.

3. Hasil perhitungan statistik deskriptif mutu pendidikan di Madrasah Tsanawiyah se-Kecamatan Gantarang Kabupaten Bulukumba diperoleh rata-rata yaitu 87,28 berada pada kategori sedang.

4. Hasil perhitungan statistik inferensial diperoleh $p$-value $<\alpha(0,010<0,05)$ sehingga $\mathrm{H}_{0}$ ditolak dan $\mathrm{H}_{1}$ diterima. $\mathrm{Hal}$ ini berarti bahwa terdapat pengaruh kompetensi supervisi kepala madrasah terhadap mutu pendidikan di Madrasah Tsanawiyah se-Kecamatan Gantarang Kabupaten Bulukumba.

5. Hasil perhitungan statistik inferensial diperoleh $p$-value $<\alpha(0,015<0,05)$ sehingga $\mathrm{H}_{0}$ ditolak dan $\mathrm{H}_{1}$ diterima. Hal ini berarti bahwa terdapat pengaruh kompetensi manajerial kepala madrasah terhadap mutu pendidikan di Madrasah Tsanawiyah se-Kecamatan Gantarang Kabupaten Bulukumba.

6. Hasil perhitungan statistik inferensial diperoleh $p$-value $<\alpha(0,005<0,05)$ sehingga $\mathrm{H}_{0}$ ditolak dan $\mathrm{H}_{1}$ diterima. Hal ini berarti bahwa terdapat pengaruh kompetensi supervisi dan manajerial kepala madrasah secara bersama-sama terhadap mutu pendidikan di Madrasah Tsanawiyah se-Kecamatan Gantarang Kabupaten Bulukumba.

\section{Saran}

1. Kepala madrasah hendaknya meningkatkan kompetensi supervisi dan manjerialnya agar mampu mengaplikasikan kemampuannya demi terwujudnya mutu pendidikan yang lebih baik.

2. Mutu pendidikan bukan hanya tanggung jawab kepala madrasah, namun tanggung jawab semua elemen yang terlibat langsung maupun tidak langsung dalam dunia pendidikan.

3. Kepala madrasah sebagai pimpinan tertinggi di lingkup madrasah hendaknya melakukan kegiatan supervisi dengan maksimal agar tumbuh tanggung jawab yang tangguh di dalam diri seorang guru. Tanggung jawab guru dalam melaksanakan kegiatan pembelajaran di dalam dan luar kelas memungkinkan terwujudnya prestasi akademik dan non akademik perserta didik yang cemerlang, sehingga menjadi cerminan mutu pendidikan yang baik.

4. Kepala madrasah sebagai manager hendaknya mengerahkan seluruh kompetensi manajerialnya dengan merangkul dan mendayagunakan seluruh sumber daya yang ada demi terwujudnya mutu pendidikan yang baik di madrasah pada khususnya, dan mutu pendidikan Indonesia pada umumnya.

5. Seluruh pemangku jabatan di lingkup pendidikan hendaknya membuat terobosan yang inovatif demi pemerataan mutu pendidikan Indonesia yang lebih baik.

6. Pemerintah mengembangkan kurikulum dengan tujuan untuk mempersiapkan peserta didik dalam menghadapi tantangan masa depan melalui pengetahuan, keterampilan, sikap, keahlian untuk beradaptasi serta bisa bertahan hidup dalam lingkungan yang senantiasa berubah. Olehnya itu, peneliti berharap pemerintah khususnya yang berkecimpung di dalam dunia pendidikan hendaknya membuat terobosan yang inovatif demi terwujudnya mutu pendidikan Indonesia yang lebih baik dan terbina peserta didik yang mampu bersaing di level nasional maupun internasional. 


\section{DAFTAR PUSTAKA}

Arikunto, Suharsimin. 2004. Dasar-dasar Supervisi,-Buku Pengangan Kuliah. Cet.1; Jakarta: PT Rineka Cipta.

Arikunto., Suharsimi. 2006. Prosedur Penelitian Suatu Pendekatan Praktik. Jakarta: PT. Rineka Cipta.

Azwar, Saifuddin. 2013. Penyusunan Skala Psikologi. Cet III, Yogyakarta: Pustaka Pelajar.

Ruky, Ahmad S. 2011. Sistem Manajemen Kinerja. Cet. III; Jakarta: Gramedia.

Ariana, I Wayan, Nyoman Dantes dan I Wayan Lasmawan. 2015. Kontribusi Supervisi Kepala Sekolah, Motivasi Berprestasi, dan Komitmen Kerja terhadap Kinerja Guru di Gugus Sekolah VII Kecamatan Abang. e-Journal Program Pascasarjana Universitas Pendidikan Ganesha Prodi Pendidikan Dasar 5.

Bermawi, Yoserizal, \& Tati Fauziah. 2015. Supervisi Kepala Sekolah terhadap Kompetensi Profesional Guru. Jurnal Pesona Dasar, 1(4).

Bush, Tony dan Mariannecoleman. 2006. Leadership dan Strategic Management In Education Manajamen Strategis Kepemimpinan Pendidikan, terj. Fahrurrozi. Yogyakarta: IRCISOD.

Fattah, Nanang. 2013. Landasan Manajemen Pendidikan. Bandung: Remaja Rosdakarya.

Fauzah. 2017. Supervisi Pendidikan sebagai Upaya Peningkatan Mutu Pendidikan Islam. Jurnal Tarbiyatuna, 2 (1).

Gunawan, Imam. 2014. Analisis Dampak Supervisi Pendidikan terhadap Perkembangan Masyarakat, IImu Pengetahuan, dan Tekhnologi, Prosiding Seminar Nasional Revitalisasi Manajemen Pendidikan Nasional Menuju Perbaikan Mental: Mandiri, Partisipatif, Efisien, \& Akuntabel.

Henny. 2012. Supervisi Kepala Sekolah dalam Meningkatkan Profesional Guru pada SMA Methodist Kota Banda Aceh, Publikasi IImiah.

Holili, Moh. 2006. Manajemen Kinerja Guru Pendidikan Agama Islam dalam Meningkatkan Mutu Pendidikan Agama Islam di SMP (Studi Kasus di SMP Negeri 5 Kota Pasuruan), Tesis (Sukorejo Situbondo: PPs Institut Agama Islam Ibrahimy).

Imron, Ali. 2012. Supervisi Pembelajaran Tingkat Satuan Pendidikan.Cet. II; Jakarta: Bumi Aksara.

Iskandar, Dedi \& Udik Budi Wibowo. 2016. Peran Pengawas Pendidikan dalam Peningkatan Mutu Pendidikan SMP di Kabupaten Bima Provinsi NusaTenggara Barat, Jurnal Penelitian IImu Pendidikan, 9 (2). 
Joenoes, Marah. 1974. Gaya Kepemimpinan Yang Sesuai Dengan Kepribadian Indonesia, Yang Dapat Mendorong Laju Pembangunan. Cet. I; Jakarta: Lembaga Minyak Dan Gas Bumi.

Kusnan. 2007. Kemampuan Manajerial Kepala Madrasah dan Implikasinya terhadap Kinerja Guru, Jurnal Iqra, 3.

Lampiran Peraturan Menteri Pendidikan Nasional Nomor 13 Tahun 2017. www.mediapendidikan.info/wp.../12/permendiknas_13-Tahun_2007sks_lamp.pdf. (online) 5Maret 2019.

Masyhud, Sulthon. 2014. Manajemen Profesi Kependidikan. Cet. I; Yogyakarta: Kurnia Alam Semesta.

Mulyasa, E. 2013. Menjadi Kepala Sekolah Profesional. Cet. XII; Bandung: PT. Remaja Rosdakarya.

Nasution, Tia Agustina. 2015. Peran Supervisi Pendidikan dalam Meningkatkan Mutu Pendidikan di Indonesia, Publikasi IImiah.

Nata, Abdullah. 2013. Manajemen Pendidikan Mengatasi Kelemahan Pendidikan Islam di Indonesia. Bogor: Kencana.

Peraturan Menteri Agama Nomor 58 Tahun 2017.pdf - Itjen Kemenag, itjen.kemenag.go.id/sirandang/files/.../551765f3a4b73170d798c0ecc2aa4c89dac2 (25 Pebruari 2018).

Purwanto, M. Ngalim. 1998. Administrasi dan Supervisi Pendidikan. Cet.VIII; Bandung: PT Remaja Rosdakarya.

RI, Kementerian Agama. 2011. Al-Qur'an dan Terjemahnya. Cet. IV; Bandung; PT Syaamil Cipta Media, 2011.

RI, Kementrian Agama. Peraturan Menteri Agama Nomor 58 Tahun 2017 tentang Kepala Madrasah, (https://hkln.kemenag.go.id/download.php?id=1490), di akses pada tanggal, 17 Desember 2018.

Riduwan dan Engkos Achmad Kuncoro. 2011. Cara Menggunakan dan Memaknai Path Analysis (Analisis Jalur). Bandung: Alfabeta.

Rivai, Veithzal. 2004. Kepemimpinan dan Prilaku Organisasi. Jakarta: PT.Raja Grafindo Persada.

Sagala, Syaiful. 2013. Kemampuan Profesionalisme Guru dan Tenaga Kependidikan. Cet. IV; Bandung: Alfabeta.

Sahertian, Piet A. dan Frans Mataheru. 1981. Prinsip dan Teknik Supervisi Pendidikan. Surabaya: UN.

Sahertian, Piet A. 2000. Supervisi Pendidikan dalam Rangka Pengembangan Sumber Daya Manusia. Jakarta: PT Rineka Cipta.

Siraj, Arifuddin. 2014. Supervisi Akademik. Cet. I; Makassar: Alauddin University Press. 
Soetopo, Hendayat, dan Wasti Soemanto. 1998. Kepemimpinan dan Supervisi Pendidikan. Jakarta: Bina Aksara.

Subroto, B. Suryo. 2004. Menejemen Pendidikan di Sekolah. Jakarta: Rineke Cipta.

Suhardiman, Budi, 2012. Studi Pengembangan Kepala Sekolah- Konsep dan Aplikasi. Cet. 1; Jakarta: Rineka Cipta.

Uno, Hamzah B. 2014. Model Pembelajaran; Menciptakan Proses Belajar Mengajar yang Kreatif dan Efektif. Cet. X; Jakarta: PT Bumi Aksara.

Usman, Husain. 2006. Manajemen Teori, Praktik, dan Riset Pendidikan. Jakarta: PT. Bumi Aksara.

Uwes, Sanusi. 1999. Manajamen Pengembangan Mutu Dosen. Cet. II; Jakarta: Logos Wacana Ilmu.

Wahjosumidjo. 2001. Kepemimpinan Kepala Sekolah, Tinjauan Teoritik dan Permasalahannya. Jakarta: Rajawali Pers.

Zuhairini dan Abdul Ghofir. 2004. Metodologi Pembelajaran Pendidikan Agama Islam. Malang: Universitas Malang. 